Polonia

JOURNAL

\title{
RELACJE EKONOMICZNE POLSKI Z NOWĄ ZELANDIĄ: STAN WSPÓŁCZESNY ORAZ PERSPEKTYWY ROZWOJU W ZWIĄZKU ZE ZWIĘKSZAJĄCĄ SIE MIGRACJĄ POLAKÓW
}

\section{POLAND'S ECONOMIC RELATIONS WITH NEW ZEALAND: CONTEMPORARY STATE AND PERSPECTIVES DEVELOPMENT IN CONNECTION WITH THE INCREASING MIGRATION OF POLES}

\begin{abstract}
ABSTRAKT
Artykuł jest próbą zilustrowania współczesnych relacji ekonomicznych Polski z Nową Zelandią, jak również przewidywanego rozwoju tejże współpracy w przyszłości. Głównym czynnikiem rozbudowy organizacji biznesowych oraz przedsiębiorstw operujących między tak dalekimi od siebie państwami jest wzmożona migracja Polaków. Stosunki dyplomatyczne łączące Warszawę z Wellington zostały zbudowane na kanwie przyjaznych relacji przedwojennych, a w głównej mierze, przyjęcia na nowo-
\end{abstract}


zelandzkie terytorium polskich sierot - „Dzieci z Pahiatua”. Oba państwa postrzegają siebie nawzajem jako godnego zaufania partnera, przedstawiciela odpowiednio Europy Centralnej oraz Pacyfiku Południowego. Stąd współpraca bilateralna ma także szansę na objęcie całego partnerskiego regionu. Z każdym rokiem współczynnik Polaków decydujących się na wyjazd tymczasowy bądź stały do Nowej Zelandii rośnie, co jest powodowane zacieśnianiem więzi prawnych poprzez trwożenie instrumentów pomocowych oraz programów współpracy.

Słowa kluczowe: Nowa Zelandia, Polonia, Polonia nowozelandzka, migracja, relacje ekonomiczne, rozwój

\begin{abstract}
The article is an attempt to illustrate contemporary economic relations between Poland and New Zealand, as well as the anticipated development of this cooperation in the future. The main factor enabling the business organizations and enterprises operation between such far-away countries is indeed the increased migration of Poles. Diplomatic relations between Warsaw and Wellington were built on the basis of friendly pre-war contacts, and primarily the reception of "Pahiatua Children", the Polish orphans on the New Zealand territory. Both states perceive one another as trustworthy partners, representatives of the Central Europe and the South Pacific respectively. Therefore bilateral cooperation also has a chance to cover the entire partner region. With each passing year, the rate of Poles deciding on a temporary or permanent visit to New Zealand is growing, which is caused by bringing closer legal ties through establishing aid instruments and cooperation schemes.
\end{abstract}

Keywords: New Zealand, Polish diaspora, Polonia, Poles in New Zealand, migration, economical relations, development

WSTECP

Polska i Nowa Zelandia, pomimo ogromnych odległości geograficznych, a także różnic ustrojowych, utrzymują przyjazne relacje poli- 
tyczne, kulturowe, a także ekonomiczne. Bez wątpienia bliska współpraca, niebędąca wszak jedną z priorytetowych, odzwierciedla uznanie dla geopolitycznych ról, jakie państwa te pełnią w swoich regionach: Polska w Unii Europejskiej oraz Europie Środkowej oraz Nowa Zelandia na kontynencie australijskim. Co należy podkreślić już we wstępie to fakt, iż Polska utrzymywała stosunki konsularne, a następnie i dyplomatyczne, z Nową Zelandią już w latach 30. XX w. ${ }^{1}$. Przed II wojną światową funkcjonował w Wellington Konsulat Generalny RP. Koniec zmagań wojennych oznaczał dla Polski przejście pod faktyczną władzę Związku Radzieckiego, z którym nowozelandzkie władze nie chciały utrzymywać stosunków. Na fali odwilży w post wojennej dyplomacji, stosunki młodego tworu państwowego, jakim od 1947r. była, wreszcie niezależna od polityki w Londynie, Nowa Zelandia wraz z krajem nad Wisłą nabrały obrotu. I choć o więzach politycznych wciąż nie było mowy, postawiono na współpracę gospodarczą. Otóż w 1965r. podpisano pierwszą umowę będącą właśnie porozumieniem handlowym, w wyniku którego zezwolono władzom PRL na utworzenie placówki handlowej w stolicy Nowej Zelandii. W kolejnym roku wyrażono zgodę na ustanowienie Konsulatu Generalnego. Trzy lata później, w 1969 r., podporządkowano ten urząd Ministerstwu Handlu Zagranicznego. Konsulat nie spełniał wszak swoich zadań, oficjalnie z przyczyn ekonomicznych. Jednak to pracownicy nie byli w stanie nawiązać kontaktów z nowozelandzką Polonią, która nie akceptowała przedstawicieli komunistycznych władz. Oficjalne stosunki dyplomatyczne nawiązano dnia 1 marca 1973 r. Należy podkreślić, iż w okresie stanu wojennego, aż do 1989 r., polsko-nowozelandzkie

${ }^{1}$ Opisy zaczynu polsko-nowozelandzkich stosunków dyplomatycznych poprzez przyjęcie polskich sierot w 1944r. oraz starań i twórczej postawy Konsula Generalnego Kazimierza Wodzickiego zostały opublikowane w poprzednich numerach „Polonia Journal". Por. J. Siekiera, Historia Dzieci z Pahiatua - z Kresów na Antypody, Nr 8/2018 oraz idem, Prof. Kazimierz hr. Wodzicki - filozof i dyplomata w stużbie Polonii nowozelandzkiej, Nr 9/2019. 
stosunki dyplomatyczne uległy zamrożeniu [Kałuski 2006, s. 164-165]. Wówczas to placówka w Australii - biuro radcy handlowego w Sydney - zmuszone było wypełniać funkcje związane $z$ wymianą handlem nie tylko zgodnie ze swoją kompetencją terytorialną, ale ponadto de iure niezgodnie $z$ własnym przeznaczeniem².

XXI w. w relacjach Polski z Nową Zelandią to już równorzędne partnerstwo oraz rozwój inicjatyw polonijnych, wprowadzanie instrumentów prawnych, a także ekonomicznych programów nastawionych na wzrost wymiany bilateralnej. Najpierw otworzono polską ambasadę w Wellington (do 2004 r. ambasador akredytowany był z Canberry) oraz jej nowozelandzki odpowiednik w Warszawie (do 2005 r. Polska znajdowała się pod zwierzchnictwem terytorialnym Ambasady Nowej Zelandii w Berlinie), a następnie zniesiono wizy turystyczne (dla Nowozelandczyków w 2004 r. w związku z przystąpieniem Polski do struktur ówczesnych Wspólnot Europejskich ${ }^{3}$, podczas gdy Polacy zostali zwolnieni z tego wymogu rok później). Dodatkowo, ze względu na relatywnie liczną Polonię, jak na ogół populacji mieszkańców Nowej Zelandii ${ }^{4}$, oraz związane z tym możliwości współpracy gospodarczej i wymiany handlowej, od 1999 r. funkcjonuje w Auckland Konsulat Honorowy, a od 2011 r. - w Christchurch.

Przytoczone powyżej fakty opisujące dwustronne relacje na linii Warszawa-Wellington dają podstawy dla kolejnych pokoleń Polaków

${ }^{2}$ Wywiad autorki z dr Dariuszem Zdziechem, prezesem Towarzystwa Naukowego Australii, Nowej Zelandii i Oceanii (ANZORA), Kraków 20.05.2019.

${ }^{3}$ Mowa tu o harmonizacji prawa krajowego do funkcjonujących wcześniej norm wspólnotowych. Rozporządzenie Rady Wspólnot Europejskich nr 539/2001 z dnia 15 marca 2001 r. wprowadziło bowiem zwolnienie z obowiązku posiadania wizy przez obywateli Australii oraz Nowej Zelandii przy wjeździe turystycznym na teren państw ówczesnej Wspólnoty. Przepis ten następnie utrzymał swoją ważność w ramach zreformowanej struktury - Unii Europejskiej.

${ }^{4}$ Zgodnie z rządowym Stats NZ, populacja na dzień 31 marca 2019 r. wynosi 4957400 osób. Dane z: https://www.stats.govt.nz/ [dostęp 17 czerwca 2019 r.] 
migrujących do Nowej Zelandii na rozwój swoich przedsiębiorstw. To również realne, bo przejawiające się w obowiązujących umowach handlowych, szanse dla polskich przedsiębiorców na wejście na nowozelandzki rynek.

\section{POLSKA MIGRACJA DO NOWEJ ZELANDII}

Polacy emigrowali do Nowej Zelandii już w latach 70. XIX w., co związane było $\mathrm{z}$ akcją osiedleńczą na ziemiach przejętych od (de facto zagrabionych) Maorysom. W literaturze przedmiotu wyróżnia się cztery główne fale wychodźstwa polskiego do Aotearoa ${ }^{5}$ osadniczą, wojenną, solidarnościową i współczesną. Niektórzy podają także dodatkowe, „pośrednie” etapy emigracji: międzywojennej, komunistycznej i scalania rodzin ${ }^{6}$. Za pierwszą falę polskiej emigracji do Nowej Zelandii przyjmuję się rok $1872^{7}$, kiedy to osadnicy z zaboru pruskiego, w obawie przed germanizacją oraz przymusowym wcieleniem do armii zaborczej zdecydowali się na przyjazd na Antypody. Polacy przybywali do nowej ojczyzny na ok. 40 statkach [Wątróbski 2011, s. 50 za: Pobóg-Jaworowski 1990, s. 61]. Przez brak polskich paszportów ani innych oficjalnych dokumentów trudno było zliczyć osoby polskiego pochodzenia, które z roku na rok coraz liczniej docierały do Nowej Zelandii. Także spisy powszechne zmieniały polskobrzmiące nazwiska na niemieckie, a z racji portu wysyłającego (ówczesne Prusy) nowozelandzcy urzędnicy traktowali Polaków jako Niemców i właśnie tak ich spisywali. Osady, w jakich

${ }^{5}$ Zamienna nazwa Nowej Zelandii w drugim oficjalnym języku maoryskim.

${ }^{6} \mathrm{~W}$ takiej poszerzonej manierze czyni to m.in. strona Ambasady RP w Wellington: https://wellington.msz.gov.pl/pl/stosunki_dwustronne/nowa_zelandia/polonia_ w_nz/polonia_w_nowej_zelandii;jsessionid=1C41702EED5AF273787D986D494EA3A1.cmsap1p [dostęp 17 czerwca 2019 r.]

${ }^{7}$ Wcześniej także obywatele polscy bądź osoby identyfikujące się jako posiadające narodowość polską odwiedzały Nową Zelandię. Trudniły się poszukiwaniem złota, walką najemną czy kupiectwem. 
osiedlali się wychodźcy znajdowały się najpierw na Wyspie Południowej (rejony Otago i Southland). Tam w latach 1880-1935 odnotowano ponad 148 nazwisk polskich osadników. Były wciąż to jedynie formalne zapisy, które nie uwzględniały wszystkich przybyłych z Rzeczypospolitej znajdującej się wówczas pod zaborami. Z kolei miejscem docelowym na Wyspie Północnej dla pierwszych polskich przybyszy była miejscowość Taranaki ${ }^{8}$. Tutaj także listy pasażerskie podają narodowości w sposób nieoddający faktów: „Kolejna nota podaje, że z grupy 186 Niemców tylko 23 tam się urodziło, pozostali zaś w liczbie 163 w Prusach”. Jak prostuje autor tego tłumaczenia: „Ci tzw. Prusacy nosili polskie nazwiska” [Wątróbski 2011, s. 95].

Pierwszą falę emigracji do Nowej Zelandii szacuje się na ok. 3,5 tys. Polaków. Po emigracji zarobkowej przyszła kolej na wychodźców wojennych: Dzieci z Pahiatua (733 wraz z 103 opiekunami), 300 polscy Żydzi, byli żołnierze, więźniowie obozów (250 osób), a także uczestnicy Powstania Warszawskiego oraz 850 tzw. displaced persons już po zakończeniu II wojny światowej [Zdziech 2007, s. 24]. Do lat 70., w ramach łączenia rodzin, w tym przez obozy tranzytowe głównie na terenie $\mathrm{Au}$ strii, do Nowej Zelandii dotarło nieco ponad 1 tys. osób ${ }^{9}$, co dało wówczas w spisie powszechnym wynik 3,5 tys. osób polskiego pochodzenia na terenie Wyspy Północnej i Południowej. Wciąż należy mieć tutaj baczenie na niemiarodajne metody pobierania danych statystycznych. Emigracja solidarnościowa w latach 80. dodała kolejnych 300 Polaków. Natomiast post solidarnościowe wychodźstwo, już w latach 90. XX w.

${ }^{8}$ W miasteczku tym założono w $1992 \mathrm{r}$. fundację „Polish Genealogical Society of New Zealand”, która miała zajmować się poszukiwaniem przodków polskiego pochodzenia. Jednak z powodu śmierci jej założyciela - dr Jerzego Pobóg-Jaworowskiego a także jego współpracowników, faktyczna działalność została zawieszona. Nie działa także od dawna nieaktualizowana strona internetowa.

${ }^{9}$ Wywiad autorki z Mariuszem Tarnawskim działającym w lokalnych organizacjach polonijnych, Hamilton 9.04.2015. 
nie miało nic wspólnego z ucieczką przed politycznymi represjami, ale ze swobodnym wyborem lepszego statusu życiowego. Inżynierowie, informatycy, lekarze czy artyści wybierali największe i najbogatsze miasto w Nowej Zelandii - Auckland. Spis powszechny z 1996 r. wykazał 3222 osoby, które za kraj pochodzenia wskazały Polskę. Stąd przyjmuje się, iż zarówno w XIX, jak i XX w. liczba Polaków, którzy wybrali, z przymusy bądź nie, Nową Zelandię jako drugą ojczyznę plasuje się na 6 tys. ${ }^{10}$. Często jednak państwo na Antypodach nie było pierwszym wyborem, ale konsekwencją wcześniejszej pracy w Irlandii czy Wielkiej Brytanii, przywyknięciem do kultury anglosaskiej oraz gotowością do wyjazdu na drugą półkulę, za czym przemawiało widmo wolniejszego trybu życia oraz dogodnych pracowniczych warunków wychowania dzieci ${ }^{11}$.

Wiek XXI to już nie tak intensywna emigracja jak w wiekach poprzednich. Jednak co istotne, to fakt, iż także współcześnie liczba Polaków w Nowej Zelandii kształtuje się na 6 tys. (nieoficjalna liczba mówi jednak o 7 tys. co odnosi się wszak do osób, które nie mówią w języku polskim ani nie posiadają polskiego czy podwójnego obywatelstwa). Natomiast nowozelandzka strona znacznie zaniża ten współczynnik nawet na 5 tys. ${ }^{12}$ Ponadto, co roku ponad 2,5 tys. polskich obywateli odwiedza Wyspę Północną lub Południową w ramach wyjazdów turystycznych, a także w ramach wiz studenckich czy pracowniczych ${ }^{13}$.

10 Dane za Woźnik Józef (2007), Na końcu świata. Emigracja z Polski do Nowej Zelandii, „Pismo PG” Nr 9.

${ }^{11}$ Wywiad autorki z dr Agnieszką Dawidowska, pomysłodawczynią wielu inicjatyw m. in. polskiej szkoły i klubu dla dzieci w Auckland oraz elektronicznego miesięcznika „Gazeta Polonia”, Auckland 2.01.2016.

${ }^{12}$ New Zealand Foreign Affairs and Trade: https://www.mfat.govt.nz/en/countries-and-regions/europe/poland/ [dostęp 17 czerwca 2019 r.]

${ }^{13}$ Wywiad autorki z Ambasadorem RP w Nowej Zelandii Zbigniewem Gniatkowskim, Wellington 8.03.2016. 


\section{WSPÓŁPRACA EKONOMICZNA}

Wspomniana wcześniej pierwsza umowa pomiędzy PRL a Nową Zelandią dotyczyła taryf celnych, a obowiązywała do czasu wstąpienia Polski do Unii Europejskiej. Współcześnie oba kraje wiążą normy trzech z czterech podpisanych porozumień dwustronnych. Są to: Umowa w sprawie unikania podwójnego opodatkowania i zapobiegania uchylaniu się od opodatkowania w zakresie podatków od dochodu z 2005 r. ${ }^{14}$; Umowa w sprawie Programu Zwiedzaj i Pracuj (Working Holiday Scheme) z 2008 r. ${ }^{15}$; Umowa w sprawie koprodukcji filmowej z października 2015 r. ${ }^{16}$; Umowa o komunikacji lotniczej, podpisana w Auckland w 2018 r. ${ }^{17}$. Jako, że polski system prawny, w tym gospodarczy, funkcjonuje w szerszym regionalnym - europejskim, większość postanowień regulowanych jest przez prawo europejskie.

Polskie Ministerstwo Przedsiębiorczości i Technologii (MPiT) podaje następujące dane obrazujące współczesną (za rok 2018) wymianę handlową między omawianymi państwami. Dwustronne obroty handlowe wzrosły o 49\% (do $315 \mathrm{mln}$ USD) co jest kontynuacją bezprecedensowego wzrostu z lat ubiegłych. Dla porównania, rok 2014 zakończono z obrotami ponad 111,2 mln USD, co już wówczas wskazywało

${ }^{14}$ Umowa między Rzecząpospolitą Polską a Nową Zelandią w sprawie unikania podwójnego opodatkowania i zapobiegania uchylaniu się od opodatkowania w zakresie podatków od dochodu, podpisana w Warszawie dnia 21 kwietnia 2005 r. (Dz. U. 2006 nr 248 poz. 1822).

${ }^{15}$ Umowa między Rządem Rzeczypospolitej Polskiej a Rządem Nowej Zelandii w sprawie Programu Zwiedzaj i Pracuj (Working Holiday Scheme), podpisana w Warszawie dnia 9 maja 2008 r. (Dz. U. 2010 nr 70 poz. 449).

${ }^{16}$ Umowa między Rządem Rzeczypospolitej Polskiej a Rządem Nowej Zelandii w sprawie koprodukcji filmowej, podpisana w Warszawie dnia 21 października 2015 r. (M.P. 2016 poz. 313).

${ }^{17}$ Umowa między Rządem Rzeczypospolitej Polskiej a Rządem Nowej Zelandii o komunikacji lotniczej, podpisana w Auckland dnia 22 sierpnia 2018 r. (test umowy nie został jeszcze inkorporowany do polskiego system prawnego). 
zwyżkę o 26\% w porównaniu z rokiem 2013. Eksport polskich towarów do Nowej Zelandii także utrzymał tendencję wzrostową z roku 2017, przy jednoczesnym wzroście importu. Polskie ministerstwa odnotowały korzystne saldo wymiany handlowej na poziomie 59,4 mln USD. MPiT przywołuje podobne wyliczenia Głównego Urzędu Statystycznego partnera - Stats NZ. Wśród najczęściej eksportowanych towarów z Polski znalazły się: 1) pojazdy, turbiny i części silników turboodrzutowych i turbośmigłowych, 2) preparaty piorące i czyszczące, leki, 3) mrożone mięso wieprzowe. Import z Nowej Zelandii także przedstawia porównywalne w latach pozycje: 1) mrożone filety rybne i skorupiaki, 2) konstrukcje i części z żelaza oraz stali, 3) wino, 4) urządzenia mleczarskie, w tym kazeina. ${ }^{18}$

Rys. 1. Wielkość eksportu i importu pomiędzy Polską a Nową Zelandią w latach 2008-2018

Wielkość obrotów handlowych Polskiz Nową Zelandią (w tys. USD)

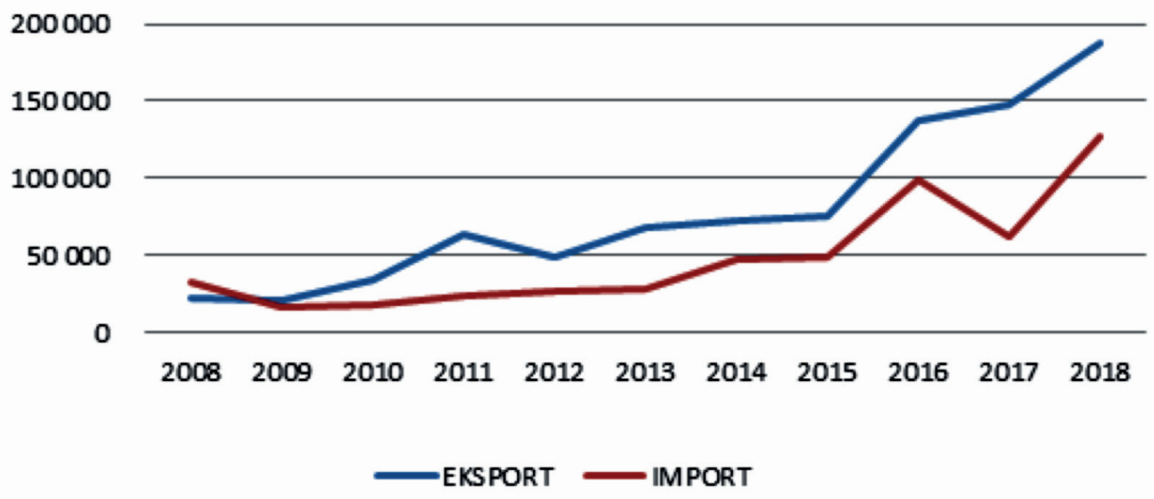

Źródło: Informator Ekonomiczny MSZ: https://informatorekonomiczny.msz. gov.pl/pl/australia/nowa_zelandia/[dostęp 17.6.2019 r.].

${ }^{18} \mathrm{Za}$ : Informatorem Ekonomicznym polskiego MSZ: https://informatorekonomiczny.msz.gov.pl/pl/australia/nowa_zelandia/ [dostęp 17 czerwca 2019 r.] 
Polski „Portal Promocji Eksportu” wymienia branże, w których Polacy mają duże szanse na rozwój swoich przedsiębiorstw, rozpoczynając jednak od podania dogodnych warunków, jakie przemawiają za inwestowaniem w kraju Aotearoa. Otóż kwestia, która powinny przeważyć w wyborze Nowej Zelandii jako miejsca prowadzenia biznesu to de facto podstawowa charakterystyka jej stabilnego systemu gospodarczego: przejrzysty i efektowny system podatkowy sprzyjający inwestycjom, wielość programów wsparcia biznesu i innowacji, najniższy na świecie wskaźnik korupcji, wysokie wynagrodzenia połączone z niskimi kosztami infrastruktury, niska inflacja, a także wydajne i otwarte systemy regulacyjne. ${ }^{19}$ Za branże perspektywiczne uznano: usługi i produkty dla rolnictwa i leśnictwa, produkty dla sektora przetwórstwa spożywczego, zwłaszcza mleczarskiego, produkty dla przemysłu, w tym głównie filmowo-telewizyjnego oraz energetycznego, czyste technologie, przemysł stoczniowy i szkutniczy, turystyka hotelowa, produkcja żywności i win, a także technologie i rozwiązania komunikacyjno-informacyjne ${ }^{20}$.

Za perspektywy rozwoju współpracy ekonomicznej należy uznać liczne przedsięwzięcia, jak przede wszystkim skutkujące realnymi rozwiązaniami dwustronne wizyty polityków ${ }^{21}$ czy udział polskich przed-

19 Portal Promocji Eksportu: https://www.trade.gov.pl/pl/analizy-rynkowe/ australia-i-oceania/nowa-zelandia/247451,informacje-praktyczne-dla-polskiego-eksportera-nowa-zelandia.html\# / [dostęp 17 czerwca 2019 r.]

${ }^{20}$ Ibidem; broszura informacyjna Ambasady RP w Wellington: Rynek nowozelandzki: Przewodnik dla polskich przedsiębiorców, Wellington 2017.

${ }^{21}$ Ostatnie wizyty to: z polskiej strony wizyta Prezydenta RP Andrzeja Dudy w sierpniu 2018 r. co oprócz pierwszej wizyty państwowej do Nowej Zelandii było okazją do rozmów z Ministrem Handlu i Rozwoju Eksportu Davidem Parkerem, a także wizyta szefa Gabinetu Prezydenta Krzysztofa Szczerskiego w sprawie procesu ustanawiania strefy bezcłowej z UE w grudniu 2017 r.; z nowozelandzkiej strony to udział Ministra ds. Zmiany Klimatu Jamesa Shawa w katowickim szczycie klimatycznym COP24 w grudniu 2018 r. oraz przyjazd w grudniu 2016 r. Todda McClaya, Ministra Handlu, który spotkał się z polskimi politykami i przedstawicielami biznesu. 
siębiorców w targach na terenie Nowej Zelandii. Dobrym tego przykładem jest misja Ministerstwa Środowiska wysłania 15 przedstawicieli firm zajmujących się tzw. zieloną technologią na „GreenEvo: Technology Acceleration”. Prestiżowe targi co roku skupiają przedstawicieli małych i średnich firm zajmujących się odnawialnymi źródłami energii, gospodarką odpadami oraz gospodarką wodno-ściekową, a zatem tematami niezwykle ważnymi dla przeciętnego Nowozelandczyka. Co należy podkreślić, jedynie Polska miała swoje narodowe stanowisko, a na prelekcje prowadzone przez polskich urzędników oraz biznesmenów przychodziły tłumy wizytujących targi ${ }^{22}$.

Także w 2015 r. powstało istotne przedsięwzięcie, które ma w swoim statucie wspieranie ekonomicznej współpracy polsko-nowozelandzkiej, w tym pomoc w odnajdywaniu odpowiedników przedsiębiorstw w państwie partnerskim, a przez to zwiększenia wymiany gospodarczej i indeksu handlowego. Z inicjatywy Ambasady RP w Wellington na czele w Ambasadorem Zbigniewem Gniatkowskim, a także Konsula Honorowego Bogdana Nowaka, powstało „Polsko-Nowozelandzkie Stowarzyszenie Biznesu POLANZ”. Instytucja z siedzibą w Auckland, znajdująca się pod patronatem Ministerstwa Spraw Zagranicznych, skupia prywatnych inwestorów na terenie Nowej Zelandii, którzy już współpracują z Polską albo mają zamiar poszerzenia swojej działalności na rynek nad Wisłą z perspektywą wykorzystania Warszawy jako bazy na eksport do Unii Europejskiej. ${ }^{23}$

Nie bez znaczenia pozostaje także fakt niebagatelnej aktywności Ambasady RP, Konsulatu Generalnego oraz dwóch Konsulatów Honorowych, których to przedstawiciele regularnie spotykają się z regionalnymi Izbami Handlowymi poszczególnych regionów czy miast w Nowej

${ }^{22}$ Autorka uczestniczyła w targach GreenEvo w Auckland 18 kwietnia 2015 r. jako obserwator polskiej grupy studyjnej.

${ }^{23}$ POLANZ: http://polanz.nz/ [dostęp 17 czerwca 2019 r.] 
Zelandii ${ }^{24}$, wygłaszają przemówienia zachęcające do inwestycji w Polsce czy współpracy z polskimi przedsiębiorstwami ${ }^{25}$, a skończywszy na popularyzacji polskiego dziedzictwa i informacji gospodarczych ${ }^{26}$ celem zmniejszenia kulturowego dystansu między partnerskimi państwami. Także strona nowozelandzka organizuje za pośrednictwem Ambasady Nowej Zelandii w Warszawie Dni Biznesu (marzec 2015, październik 2016, kwiecień 2018). Jak dumnie podaje Ministerstwo Spraw Zagranicznych i Handlu: „Te dni pomogły pokazać zarówno polskim, jak i nowozelandzkim przedsiębiorstwom jak wyglądają biznesowe perspektywy pomiędzy naszymi krajami”27.

\section{ZAKOŃCZENIE}

Zwiększającą migrację Polaków do Nowej Zelandii odnotowywano od początku historii państwowości tego państwa. Choć wielokrotnie nie uwzględniano rzeczywistej narodowości polskich wychodźców sugerując się państwami zaborczymi, z których wypływali osadnicy bądź też nieumiejętnie zmieniano ich polsko brzmiące nazwiska. Dla ścisłości, na zakończenie niniejszego artykułu należy przywołać interesujcie zostawienie dokonane na podstawie oficjalnych spisów ludności. Zgod-

${ }^{24}$ Jak chociażby spotkania Konsul Winsome Dormer z Izbą Handlową Otago, która leży w okręgu konsularnym pani Konsul. Wywiad autorki z Winsome Dormer, Christchurch 16.03.2015.

${ }^{25} \mathrm{Tu}$ za przykład może posłużyć seminarium polskich dyplomatów podczas targów mięsnych „European Meat-tradition, quality and taste” 24 czerwca 2016 r. w Auckland.

${ }^{26}$ Wydana w 2018 r. broszura informacyjna 45 Years of Diplomatic Relations Poland \& New Zealand: Friendship, Partnership, Cooperation jest zbiorem szczegółowych danych oraz opisem, co udało się osiągnąć przez okres współczesnych relacji dyplomatycznych. Została ona celowo opublikowana jedynie w języku angielskim, co jasno wskazuje na adresatów informatora.

${ }_{27}$ Tłumaczenie autorki na podstawie: https://www.mfat.govt.nz/en/countriesand-regions/europe/poland/ [dostęp 17 czerwca 2019 r.] 
nie z nim, ilość rezydentów Nowej Zelandii urodzonych w państwie polskim przedstawiała się następująco: w spisie przeprowadzonym w 1874 r. - 60; 1901 - 97; 1951 - 2 003; 1976 - 2 034; 2001 - 1 938; 2006 - 2 004; 2013 - 1 944, z czego poczucie polskiej tożsamości etnicznej wykazało odpowiednio w roku 20061965 respondentów, a w ostatnim spisie w 2013 r. - $2163^{28}$. Jak zostało jednak wyjaśnione w tekście, liczby te nie oddają realnych wartości, a Polaków oraz osób narodowości polskiej znajdującej się w Nowej Zelandii nawet 7 tys., nie licząc regularnie napływających turystów czy osób przybywających na wizach tymczasowych. Dawało to i wciąż daje ogromny wachlarz możliwości umacniania relacji ekonomicznych pomiędzy Polską a Nową Zelandią. Perspektywy rozwoju stosunków gospodarczych są opierane na coraz to nowych instrumentach prawnych, rozwiązaniach biznesowych, spotkaniach promocyjnych polityków czy przedstawicieli rządowych agencji rozwoju. Daje to realną szansę małym i średnim przedsiębiorstwom polskim i nowozelandzkim na poszerzenie swojego rynku zbytu nie tylko na państwo partnerskie, ale i jego region. Widać tego efekty w rok rocznie zwiększającym się indeksie wymiany handlowej, otwarciu na siebie nawzajem rynków, ale i świadomości Polaków oraz Nowozelandczyków na zyski, jakie niesie ze sobą inwestycja w tak odległym geograficznie acz blisko związanym historycznie i kulturowo kraju.

${ }^{28}$ Wpisu „Poles - Facts and figures” na Te Ara - the Encyclopedia of New Zealand dokonała prof. Theresa Sawicka z Victoria Univeristy of Wellington: http://www. TeAra.govt.nz/en/poles/page-4 [dostęp 17 czerwca 2019 r.] 


\section{BIBLIOGRAFIA:}

\section{Literatura:}

Kałuski M., Polacy w Nowej Zelandii, Oficyna Wydawnicza Kucharski, Toruń 2006.

Pobóg-Jaworowski J., W., History of the Polish settlers in New Zealand, Ars Polona, Warszawa 1990.

Wątróbski L., Polskie osadnictwo w Nowej Zelandii 1872-1983, Uniwersytet Szczeciński, Szczecin 2011.

Woźnik J., Na końcu świata. Emigracja z Polski do Nowej Zelandii, „Pismo PG” 2007 nr 9.

Zdziech D., Pahiatua - „Mała Polska” małych Polaków, Towarzystwo Naukowe Societas Vistulana, Kraków 2007.

\section{Źródła informatyczne:}

Strona internetowa Ambasady RP w Wellington: https://wellington.msz.gov. pl/pl/stosunki_dwustronne/nowa_zelandia/polonia_w_nz/polonia_w_ nowej_zelandii;jsessionid=1C41702EED5AF273787D986D494EA3A1. cmsap1p [dostęp 17 czerwca 2019 r.].

Strona internetowa Informatora Ekonomicznego MSZ: https://informatoreko nomiczny.msz.gov.pl/pl/australia/nowa_zelandia/ [dostęp 17 czerwca 2019 r.].

Strona internetowa New Zealand Foreign Affairs and Trade: https://www.mfat. govt.nz/en/countries-and-regions/europe/poland/ [dostęp 17 czerwca 2019 r.].

Strona internetowa Portalu Promocji Eksportu: https://www.trade.gov.pl/ pl/analizy-rynkowe/australia-i-oceania/nowa-zelandia/247451, informacje-praktyczne-dla-polskiego-eksportera-nowa-zelandia.html\#/ [dostęp 17 czerwca 2019 r.].

Strona internetowa Te Ara - the Encyclopedia of New Zealand: http://www. TeAra.govt.nz/en/poles/page-4 [dostęp 17 czerwca 2019 r.]. 
Inne:

Broszura informacyjna Ambasady RP w Wellington: 45 Years of Diplomatic Relations Poland \& New Zealand: Friendship, Partnership, Cooperation, Wellington 2018.

Broszura informacyjna Ambasady RP w Wellington: Rynek nowozelandzki: Przewodnik dla polskich przedsiębiorców, Wellington 2017.

Wywiad autorki z Agnieszką Dawidowska, Auckland 2.01.2016.

Wywiad autorki z Dariuszem Zdziechem, Kraków 20.05.2019.

Wywiad autorki z Mariuszem Tarnawskim, Hamilton 9.04.2015.

Wywiad autorki z Winsome Dormer, Christchurch 16.03.2015.

Wywiad autorki ze Zbigniewem Gniatkowskim, Wellington 8.03.2016. 